\begin{tabular}{lccc} 
VERSITA & GOSPODARKA & SUROWCAMI & MINERALNYMI \\
\hline \multirow{2}{*}{ Tom 29} & 2013 & Zeszyt 3 \\
& & DOI 10.2478/gospo-2013-0035 &
\end{tabular}

\title{
Flotation Method in Talc Raw Material Processing from the Gemerská Poloma Deposit in Slovakia
}

\section{Introduction}

The deposit of talc raw material in Gemerská Poloma, located in the central part of the Spiš-Gemer Rudohorie mountain range and under the main edge of the Volovec Mount in Slovakia, is categorized as one of the most important deposits of this raw material in Europe due to its qualitative and quantitative parameters. The main mineral in the deposit is talc representing a part of a large carbonate body of lenticular shape with a mainly magnesite composition.

The character of talc, its quality, and technological parameters, as well as the size of stock predetermine profitable usage. At present, about 10 thousand tons of the raw material are mined and construction of a mining and conditioning complex within an optimal distance from the deposit is being considered. The plan for annual raw material processing amounts to as much as 100,000 tons (with an assumption of a future increase in the finishing mill capacity). The proposed talc conditioning is based on mechanical crushing of the raw material, grinding in a ball mill, flotation, filtration, and drying of the flotation concentrates talc and magnesite.

* Ing., PhD., Institute of Montaneous Sciences and Environmental Protection, Faculty of Mining, Ecology, Process Control and Geotechnologies, Technical University, Košice, Slovak Republic, e-mail: marina.sidorova@tuke.sk

** Ing., PhD., Mining\&Economy Consulting s.r.o., Košice, Slovak Republic, e-mail: peter.corej1@gmail.com 
The deposit's raw materials, after adequate conditioning, present opportunities for application in many industries pharmaceutical, colorants, varnishes, plastics, ceramics, paper, rubber, chemical, textile, leather, construction, etc.

\section{Chemical and qualitative characteristics of talc}

Results of analytical, mineralogical, chemical, and technological analyses show that talc found in the deposit is in a very clean condition. Talc has extraordinarily favourable qualitative chemical and technological properties. It contains a minimum amount of additional agents. The main impurities include magnesite, dolomite, and silica. Mechanical removal of these components by manual separation increases talc quality. Chlorite, causing significant impurity when present in talc deposits, is present at the deposit in Gemerská Poloma at negligible levels. The quality is also partially affected by the presence of pyrite

TABLE 1

Chemical and mineral compositions of various types of minerals located at the deposit in Gemerská Poloma

Skład chemiczny i mineralny różnych typów mineralnych w złożu Gemerská Poloma

\begin{tabular}{|c|c|c|c|c|c|c|}
\hline $\begin{array}{c}\text { Component } \\
{[\%]}\end{array}$ & Talc & $\begin{array}{l}\text { Talc with } \\
\text { magnesite }\end{array}$ & $\begin{array}{l}\text { Magnesite with } \\
\text { intergranular talc }\end{array}$ & Magnesite & $\begin{array}{c}\text { Dike silica, } \\
\text { dolomite, talc }\end{array}$ & $\begin{array}{c}\text { Chloritic } \\
\text { shale }\end{array}$ \\
\hline $\mathrm{SiO}_{2}$ & 60.24 & 39.88 & 13.84 & 5.60 & 45.79 & 31.64 \\
\hline $\mathrm{Al}_{2} \mathrm{O}_{3}$ & 0.11 & 0.07 & 0.05 & 0.28 & 0.04 & 17.79 \\
\hline $\mathrm{TiO}_{2}$ & 0.001 & 0.001 & 0.004 & 0.02 & 0.001 & 0.715 \\
\hline $\mathrm{Fe}_{2} \mathrm{O}_{3}$ & 0.91 & 2.81 & 4.74 & 6.12 & 2.34 & 4.30 \\
\hline $\mathrm{FeO}$ & 0.79 & 1.91 & 4.11 & 5.25 & 0.90 & 0.68 \\
\hline $\mathrm{CaO}$ & 0.23 & 0.36 & 0.50 & 5.75 & 9.72 & 0.92 \\
\hline $\mathrm{MgO}$ & 32.04 & 35.66 & 40.40 & 36.12 & 21.76 & 31.26 \\
\hline $\mathrm{AL}$ & 5.97 & 20.63 & 39.45 & 45.29 & 19.39 & 12.03 \\
\hline IR & 95.72 & 63.86 & 21.51 & 8.56 & 61.31 & 73.60 \\
\hline Talc & 95.5 & 62.2 & 20.2 & - & 38.8 & 8.2 \\
\hline Magnesite & 3.0 & 35.5 & 77.3 & 74.3 & 6.6 & - \\
\hline Dolomite & 0.7 & 1.0 & 1.2 & 18.6 & 4.4 & 3.0 \\
\hline Silica & 0.3 & 0.9 & 1.1 & 5.8 & 21.7 & 2.0 \\
\hline Chlorite & 0.5 & 0.3 & 0.2 & 1.3 & 0.2 & 86.8 \\
\hline Pyrite & 0.1 & 0.1 & 0.1 & 0.01 & 1.7 & - \\
\hline
\end{tabular}


accumulating at places in contact with magnesite. Pyrite is rather easy to remove by magnetic separation. There are minimal amounts of $\mathrm{Pb}, \mathrm{Cu}$, and $\mathrm{Cd}$. The average whiteness value is $78 \%$. Highly pure talc ores have a whiteness value of up to $90 \%$ or more.

The talc and magnesite (dolomite) composition is characterised by contents of $\mathrm{SiO}_{2}$, $\mathrm{Al}_{2} \mathrm{O}_{3}, \mathrm{TiO}_{2}, \mathrm{FeO}, \mathrm{CaO}, \mathrm{MgO}$, loss on ignition (LOI), and insoluble residue (IR). Table 1 shows the chemical composition of various mineral types located in the deposit and their mineral composition, determined by calculation based on chemical analyses (Kilík 1997).

Technological properties of talc ore in the Gemerská Poloma deposit predetermine it for industrial use, as they facilitate quality products of all quality classes to be prepared by flotation, pursuant to the respective technical standard STN 721761 (Pinka et al. 2008). Basic properties required by the standard are shown in Table 2.

TABLE 2

Talc basic properties required by the standard

Podstawowe właściwości talku wymagane przez normę

\begin{tabular}{||l|c|c|c|c||}
\hline \multirow{2}{*}{\multicolumn{1}{|c|}{ Property }} & \multicolumn{4}{|c||}{ Basic quality classes } \\
\cline { 2 - 6 } & A & B & C & D \\
\hline \hline Talc content [\%] & $\min .95$ & $90-95$ & $70-90$ & $50-70$ \\
\hline Insoluble residue in $\mathrm{HCl} \mathrm{[ \% ]}$ & $\min .95$ & $90-95$ & $70-90$ & $50-70$ \\
\hline Loss on ignition [\%] & $4.5-7$ & $4.5-9$ & $4.5-19$ & $4.5-28$ \\
\hline
\end{tabular}

\section{Talc conditioning and processing method}

There are 3 possible methods of mined talc processing:

1) manual sorting on selection belt,

2) optical sorting,

3) conditioning by flotation - foam flotation.

Manual sorting of the material is the basic method of talc processing during mining, together with selective gathering. In this method, the monitoring is focused on the presence of impurities from silica, carbonates, or pyrite, as well as colour differences in the raw material. In countries with higher wage levels, manual sorting is replaced with optical sorting which reliably sorts grains larger than $6-8 \mathrm{~mm}$. The maximum grain size in the case of manual sorting ranges from 40 to $120 \mathrm{~mm}$ (www.vsk-mining.com).

Flotation is carried out in practice with raw materials of a lower talc content. Relatively clean talc ores are conditioned only by crushing, grinding, magnetic separation, etc. Flotation 
is a method of assortment of fine-grain raw materials, based on differences in wettability with water of various minerals (Zeleň́k, Škvarla 2001; Wdowin, Gruszecka 2012).

When making a decision on which component should be used for a foam product, consideration is given to which component has a higher so-called "natural hydrophobicity", i.e. resistance to water. This hydrophobicity is increased by suitably chosen flotation reagents - collectors. Hydrophobic talc floats without a collector due to the effect of the foaming additional agent only (Luszczkiewicz et al. 2004; Bakalarz 2011). If the procedure is hydrophilic, no complications occur; only when graphitic elements are present do the two minerals fail to separate during the flotation process.

Concentrates can be grinded when dry or wet. Typical grain size up to $63 \mu \mathrm{m}$ is reached using ball, cylinder, and centrifugal mills. Modern centrifugal sorters-separators make it possible to maintain a very hard granulometric composition of grinding products.

The finest dry grinding, up to $1 \mu \mathrm{m}$ is reached by means of a jet mill using media like air, hot air, or steam.

As talc is a hydrophobic and fine material, and it is hard to disperse; these products are occasionally compressed (usually called pellets), i.e. by rolling - sample pressing with water, the material is compressed into raw bricks. After such conditioning, the material is easier to disperse and is used, for example, in the paper industry for liquidation of harmful resin.

\section{Test conditioning of talc by flotation}

An input material used as a charge in the conditioning process is magnesite-talc raw material that has to meet the requirements specified in Table 3 .

Flotation talc concentrate is not the final product of conditioning. Before being dispatched to individual customers it is further conditioned. The concentrate is assessed depending on talc content, which determines qualitative and utility parameters of the product. Talc concentrate obtained by flotation must meet the requirements specified in Table 4.

Wymagania stawiane materiałowi kierowanemu do flotacji

\begin{tabular}{||l|c||}
\hline \multicolumn{1}{|c|}{ Component } & Value [\%] \\
\hline \hline Loss on ignition & $30-45$ \\
\hline Insoluble residue & $25-40$ \\
\hline $\mathrm{Fe}_{2} \mathrm{O}_{3}$ content & $\operatorname{max.} 2.5$ \\
\hline Talc content & $\min .25$ \\
\hline
\end{tabular}


Requirements for talc concentrate obtained by flotation

Wymagania stawiane koncentratowi talku otrzymywanemu w wyniku flotacji

\begin{tabular}{|c|c|c|c|c|}
\hline \multirow{2}{*}{\multicolumn{2}{|c|}{ Qualitative indicator }} & \multicolumn{3}{|c|}{ For product type } \\
\hline & & \multirow{2}{*}{$\begin{array}{c}\text { EKII }^{1} \\
22\end{array}$} & \multirow{2}{*}{$\begin{array}{c}\text { EK III }{ }^{1} \\
22\end{array}$} & \multirow{2}{*}{$\frac{\mathrm{OO} / \mathrm{A}^{1}}{22}$} \\
\hline $\mathrm{H}_{2} \mathrm{O}$ content & $\% \max$. & & & \\
\hline $\mathrm{Fe}_{2} \mathrm{O}_{3}$ content & $\% \max$. & 1.6 & 2.5 & 2.0 \\
\hline Loss on ignition & $\% \max$. & 9 & 20 & 10 \\
\hline Insoluble residue & $\%$ max. & 83 & 60 & 80 \\
\hline Whiteness & $\% \max$. & 80 & 75 & 78 \\
\hline
\end{tabular}

${ }^{1}$ Electroceramic talc (EK I, EK II) - STN 72 1763, Pharmaceutical talc (OO/A, EK III) - STN 721764

In October 2010, operating experiments on flotation conditions were carried out within the technological and conditioning tests of the talc raw material from the Gemerská Poloma deposit, and the final version of the project for construction of talc finishing mill located in a the raw material mining area was prepared. To provide more complex assessment of the tests and comparison of the results, operating tests were carried out on two, independent technological lines conducting raw material flotation. The objective of the tests was to verify the suitability of conditioning of this raw material by flotation and at the same time to verify the suitability of the technological equipment of both flotation lines.

During both tests the input material was talc with a fraction of $0-32 \mathrm{~mm}$.

\subsection{Operating flotation tests in technological line 1-TL1}

Operating tests were carried out in two stages, differing mainly in the charge and type of foaming agent used. Used foaming agents employed were flotation reagent PEG 600 in the amount of approximately $50 \mathrm{gt}^{-1}$ of the input material, and pine oil PINE OIL 70 in the amount of 25-30 $\mathrm{gt}^{-1}$ of the input material. Sample taking was also carried out for the purpose of chemical analyses, as well as sieve tests.

Before entering the flotation line, talc was fed into the primary crusher in turns-mixed. This fact, with regard to the higher talc content in the input material, eventually had significant impact on the achieved rate of talc recovery from the charge during the process of flotation. The flotation technological scheme is shown in Fig. 1.

The total amount of talc transported and processed during technological tests in TL1 represents $154.55 \mathrm{t}$ of talc (129.25 $\mathrm{t}$ with fractions of $0-32 \mathrm{~mm}$ and $25.3 \mathrm{t}$ with fractions of $32-200 \mathrm{~mm}$ - talc with pyrite). Average humidity of the raw material was $7.8 \%$. Out of the total reported input material weight, $40 \mathrm{t}$ of talc concentrate was obtained. The flotation line 


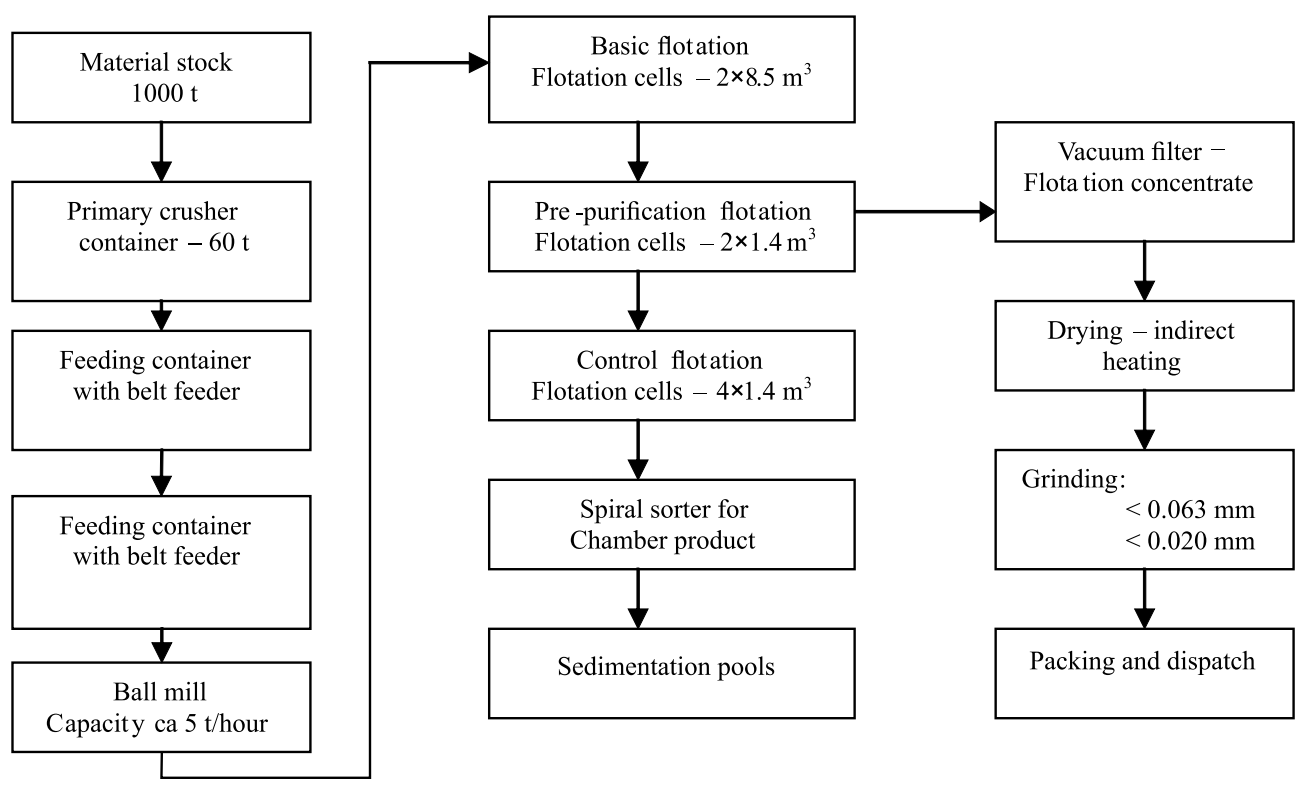

Fig. 1. Technological scheme of flotation in TL1

Rys. 1. Schemat technologiczny flotacji na linii TL1

recovery rate for fractions of $0-32 \mathrm{~mm}$ is about $22 \%$, while for talc with pyrite as the input material with fractions of $32-200 \mathrm{~mm}$ the rate $43 \%$.

The independent laboratory of the EL spol. s r.o. company the confirmed achieved whiteness values of flotation concentrate ranged from $83-84.7 \%$, and the results of laboratory analyses are shown in Table 5.

TABLE 5

Results of laboratory analyses from flotation in the TL1

TABELA 5

Rezultaty analiz laboratoryjnych z flotacji na linii TL1

\begin{tabular}{||c|c|c|c|c|c|c|c|c|c||}
\hline \multicolumn{1}{|c|}{ Sample name } & $\mathrm{SiO}_{2}$ & $\mathrm{Fe}_{2} \mathrm{O}_{3 \text { total }}$ & $\mathrm{FeO}$ & $\mathrm{CaO}$ & $\mathrm{MgO}$ & $\mathrm{S}_{\text {sulf }}$ & $\mathrm{IR}$ & LOI & Whiteness \\
\hline \hline $\begin{array}{l}\text { First concentrate } \\
\text { sample filter }\end{array}$ & 58.46 & 1.03 & 0.79 & 0.35 & 32.52 & 0.01 & 91.58 & 7.79 & 84.7 \\
\hline $\begin{array}{l}\text { Concentrate sample } \\
1^{\text {st day }}\end{array}$ & 61.46 & 0.99 & 0.79 & 0.41 & 31.73 & 0.02 & 96.65 & 5.77 & 84.6 \\
\hline $\begin{array}{l}\text { Concentrate sample } \\
2^{\text {nd day }}\end{array}$ & 60.48 & 1.08 & 0.79 & 0.48 & 31.47 & 0.02 & 95.77 & 5.99 & 83.9 \\
\hline $\begin{array}{l}\text { Waste from } \\
\text { filtration }\end{array}$ & 35.16 & 3.25 & 2.15 & 6.6 & 26.57 & 0.4 & 44.13 & 27.17 & 68.9 \\
\hline \hline
\end{tabular}




\subsection{Operating flotation tests in technological line 2 - TL2}

For the operating tests, $509 \mathrm{t}$ of talc raw material was used with fractions of $0-32 \mathrm{~mm}$ from uncovered, free raw materials stock in the operation's premises, formed by primary crushing and sorting of raw ore obtained from mining. Determined humidity values of brought the provided material with average assumed talc content up to $50 \%$ ranged from 6 to $7 \%$. The flotation technological scheme is shown in Fig. 2.

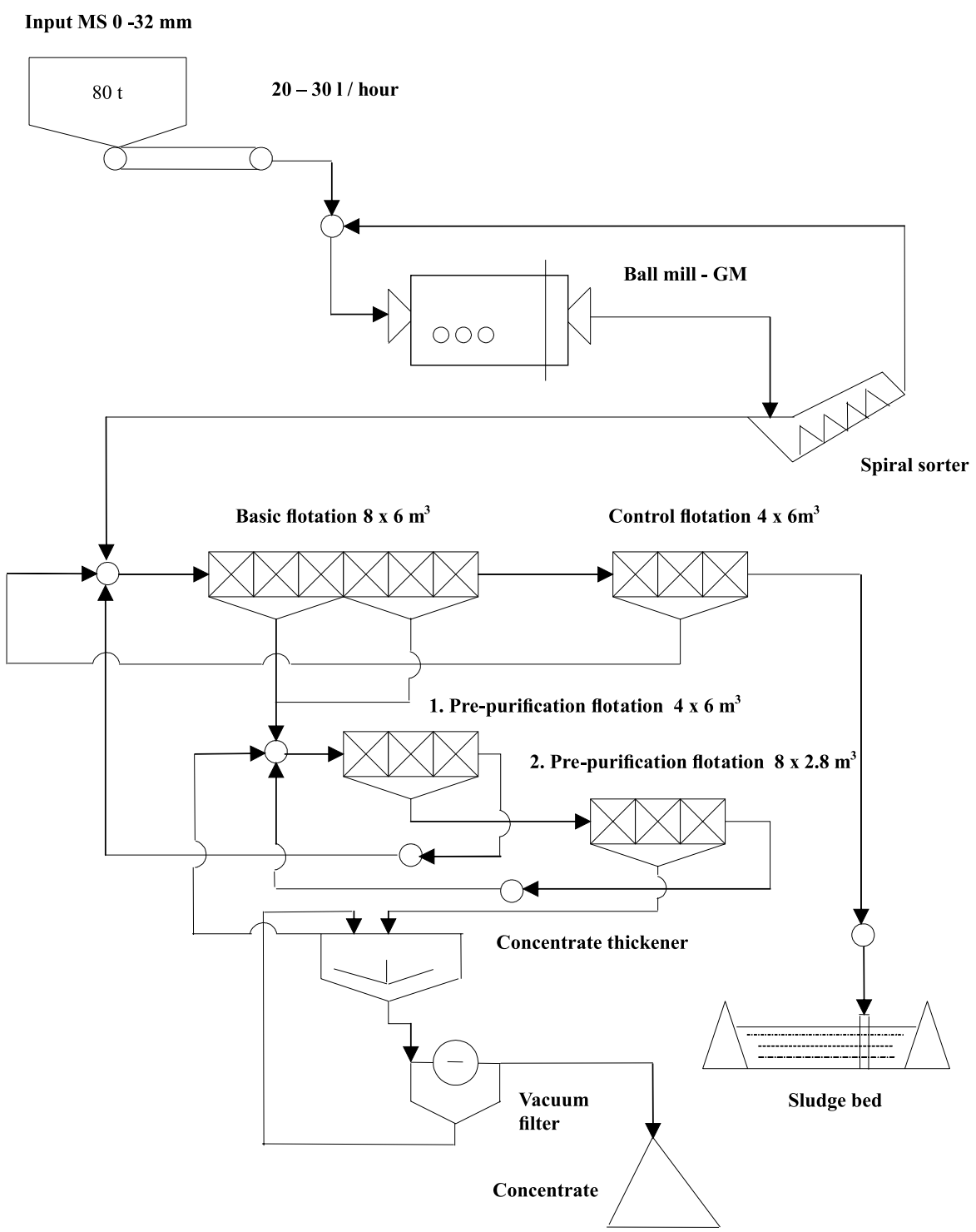

Fig. 2. Technological scheme of the functioning part of the flotation line in TL2

Rys. 2. Schemat technologiczny funkcjonalnej części flotacji na linii TL2 
The operating test was carried out using the flotation reagent FLOTANOL M (MIBC) with the recommended dose of approximately $60 \mathrm{gt}^{-1}$ of the charge, and pine oil PINE OIL 70 with the recommended dose of approximately $40 \mathrm{gt}^{-1}$ of the charge to facilitate testing of several reagents and comparison of results of their use.

Talc grinding fineness was continuously monitored during the operating experiment and ranged from 52 to $68 \%$ below $100 \mu \mathrm{m}$. Bulk weight of flotation haze on sorter decant ranged from 1,300 to $1,600 \mathrm{gl}^{-1}$.

The sampling scheme was prepared with monitored parameters in order to gather data instantaneously from the operating test for collection and preparation of daily samples including reagent dosage amount and place. Whiteness of the collected samples was measured using the Leukometer measuring device for $\mathrm{BaSO}_{4}$ etalon.

Considering the loss of about $10 \%$ on material transportation routes and in containers, the total amount of conditioned raw material is assumed to be approximately $458 \mathrm{t}$. The total weight of obtained talc concentrate represents $113 \mathrm{t}$, on the basis of which it is possible to deduct the recovery rate of the process at a level of $25 \%$, which also corresponds to theoretical calculations based on the results of laboratory analyses.

However, the independent laboratory of the EL spol. s r.o. company, having assessed the control samples, confirmed much higher whiteness levels of flotation concentrate ranging from 86.5 to $88 \%$, as shown in Table 6. Measurement results confirmed high efficiency of separation of pyrite and other minerals during operating tests, excluding very small portions of, for example, limonite which cannot be removed by flotation.

TABLE 6

Results of laboratory analyses from flotation in TL2

TABELA 6

Rezultaty analiz laboratoryjnych z flotacji na linii TL2

\begin{tabular}{||c|c|c|c|c|c|c|c|c|c||}
\hline \hline \multicolumn{1}{|c|}{ Sample name } & $\mathrm{SiO}_{2}$ & $\mathrm{Fe}_{2} \mathrm{O}_{3 \text { total }}$ & $\mathrm{FeO}$ & $\mathrm{CaO}$ & $\mathrm{MgO}$ & $\mathrm{S}_{\text {sulf }}$ & $\mathrm{IR}$ & LOI & Whiteness \\
\hline \hline $\begin{array}{l}\text { Mill entrance } \\
0-32 \mathrm{~mm}\end{array}$ & 47.69 & 2.54 & 1.43 & 5.32 & 25.94 & 0.26 & 68.42 & 16.22 & 76.9 \\
\hline $\begin{array}{l}\text { Concentrate sample } \\
\text { MIBC }\end{array}$ & 61.55 & 0.95 & 0.72 & 0.45 & 30.77 & 0.02 & 95.92 & 5.78 & 86.5 \\
\hline $\begin{array}{l}\text { Concentrate sample } \\
\text { PINE OIL 70 }\end{array}$ & 60.85 & 1.0 & 0.65 & 0.46 & 31.24 & 0.02 & 95.39 & 5.93 & 88.0 \\
\hline
\end{tabular}

It can be assumed that after grinding the product below $20 \mu \mathrm{m}$, the concentrate whiteness even rises, which is also indicated by sulphur content or pyrite content values $(0.02-0.04 \%)$, remarkably below the limit, and could have a negative impact on achieving the highest whiteness degrees. 


\section{Conclusion}

With regard to the above mentioned and achieved results of flotation concentrate whiteness it is possible to conclude that the performed experiments met the expectations concerning the quality of the final concentrate, especially in terms of a crucial parameter the concentrate whiteness whereas the final concentrate whiteness values will be known after grinding to finer fractions.

To conclude, based on macro observations and results of orientation analyses examined during the experiments, it is possible to state that conditioning by flotation of talc from the Gemerská Poloma locality is a suitable technological procedure to enrich talc into flotation concentrate and suppress accompanying mineral particles, especially pyrite. This has been confirmed by the results of chemical analyses of the obtained concentrates. Technological regimes of talc conditioning in both companies meet the requirements, though to different extents of processed raw material, for further verification of the technological conditions and after suitable thermal and granulometric conditioning into a commercial product, as well as possible marketing of the obtained concentrate. These results can be regarded as sufficient for elaboration of technical and economic study, and pre-project documentation for the technological point of flotation within the complex conditioning of talc raw material from the locality of Gemerská Poloma.

This paper was prepared with the support of the Grant Agency of the Slovak Republic VEGA number $1 / 1206 / 12$

\section{REFERENCES}

Bakalarz A., 2011 - Flotation of copper ore with n-dodecane as a collector.Gospodarka Surowcami Mineralnymi t. 27 , z. 1 , p. $69-83$

Č or e j P., 2007 - Intention. Conditioning complex Gemerska Poloma.

Č or ej P., 2010 - Intention. Increase of mining capacity and talc raw material processing from Gemerska Poloma deposit.

GENES a.s., 2010 - Technical report from flotation of talc raw material.

Kilík J., 1997 - Acta Montanistica Slovaca vol. 2, no. 1, 71-80.

Łuszczkiewicz et al. 2004 - Łuszczkiewicz A., Henc T., Muszer A., 2004 - Analiza i ocena wzbogacalności rudy o podwyższonej zawartości czarnych łupków w przypadku prowadzenia flotacji metodą standardową i przy zastosowaniu odczynników apolarnych. Praca KU-004/120/04, Centrum Badawczo-Projektowe Miedzi „Cuprum”, sp. z o.o. Ośrodek Badawczo-Rozwojowy, Wrocław.

P inka J., Witt en berger G., Šk v a re k o vá J., 2008 - Legislatíva v geologickom prieskume a vo využívaní prírodných zdrojov. Equilibria, Košice.

Zeleňák et al. 2001 - Zele ňák F., Š k v a rla J., 2001 - Acta Montanistica Slovaca vol. 6, no. 2, 143-149.

W dow in M., Grus ze ck a A., 2012 - Mineralogical-chemical and texstural characteristics of Zn-Pb industry flotation wastes with further potential for application as sorbents. Gospodarka Surowcami Mineralnymi t. 28, z. 3, p. 55-69.

http://www.vsk-mining.com/ 
METODA FLOTACYJNA W PRZERÓBCE KOPALINY TALKOWEJ ZE ZLOŻA GEMERSKÁ POLOMA NA SLOWACJI

\author{
Słowa kluczowe
}

Talk, białość, strata prażenia, pozostałość nierozpuszczalna, flotacja

\title{
Streszczenie
}

Artykuł przedstawia przydatność metody flotacyjnej w przeróbce kopaliny talkowej pochodzącej ze złoża Gemerská Poloma. Wnioski oparte są na analizie wyników badań kontrolowanych próbek materiału z prób produkcyjnych, które zostały przeprowadzone $\mathrm{w}$ dwóch instalacjach flotacyjnych. Ocena wyników tych prób przemysłowych, w tym analizy chemicznej i innych analiz jakościowych przeprowadzonych na próbkach kontrolnych, potwierdzają stosunkowo wysoki poziom białości - w zakresie od 83,9-88,0\% - w otrzymanych koncentratach talku. Wiadomo jednak, że surowiec talkowy osiągnie swój ostateczny poziom białości po jego zmieleniu do docelowej granulacji. Badania potwierdzają również wysoką skuteczność separacji pirytu i innych minerałów towarzyszących w trakcie flotacji. Na podstawie wyników analizy chemicznej koncentratów talku, uzasadnione jest stwierdzenie, że metoda flotacji może być uznana za odpowiednią metodę wzbogacania kopaliny talkowej pochodzącej ze złoża Gemerská Poloma.

Złoże talku Gemerská Poloma zostało udokumentowane pod koniec lat dziewięćdziesiątych XX wieku. W 1988 roku podczas badań geologicznych w rejonie Gemerská Poloma na końcu doliny Dlhá, w wyniku przeprowadzonych prac wiertniczych (3 otwory) stwierdzono mineralizację talkowo-magnezytową. Unikalne złoże talku może mieć duże znaczenie na rynku europejskim, będąc porównywalnym do największych światowych złóż tej kopaliny. Eksperci uważają złoże talku Gemerská Poloma pod względem wymiarów, jakości kopaliny i ilości zasobów, jako jedno z największych na świecie. Jego kluczową zaletą jest dobre strategiczne położenie w centrum Europy. Oceny ekonomiczne tego złoża dają perspektywę długoletniej zyskownej działalności produkcyjnej, a działalność ta może także częściowo ożywić górniczo-geologiczny rynek pracy w tym regionie. Popyt na ten surowiec w Europie ma stałą tendencję wzrostową.

FLOTATION METHOD IN TALC RAW MATERIAL PROCESSING FROM THE GEMERSKÁ POLOMA DEPOSIT IN SLOVAKIA

$$
\text { Key words }
$$

Talc, whiteness, annealing loss, insoluble residue, floating

$$
\text { Abstract }
$$

This article describes the suitability of the flotation method in the processing of talc raw material from the Gemerská Poloma deposit. The conclusions are based on the analysis of test results of controlled material samples from plant trials that were conducted in two flotation facilities. The evaluation of the results of the trial runs, chemical analysis, and other analyses conducted on the control mineral samples confirmed relatively high levels in the range between $83.9-88 \%$ of whiteness in the sample mineral concentrate. However, it is known that the talc will reach its final level of whiteness after it is ground into more refined particles. The trials also confirmed high effectiveness of separation of pyrite and other accompanying minerals. Based on the results of the chemical analysis of the concentrates, it is safe to conclude that the flotation method can be deemed suitable for the enriching of talc extracted from the Gemerska Poloma deposit.

The talc deposit at Gemerská Poloma was already identified in the late 90s. In 1988 during geological surveys in Gemerská Poloma at the end of Dlhá Valley, talc magnesite mineralization was found by three drillings. A unique talc deposit was verified of European significance comparable to the largest global deposits by its. Experts regard the Gemerské talc deposit in terms of its dimensions, quality, and quantity as one of the most important in the world. Its key advantage is a good strategic location in the centre of Europe. The economic prospects of this deposit are estimated to offer many years of potential benefits which will partly revive the labour market for the mining-geological specialisation. Demand for this industrial mineral in Europe has an increasing tendency 